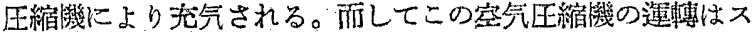
イッヂにより行ふ。害冷時譏関の起動を容易にするため潤滑 油を加熱すると同じ樣に必要に焦じ冷却水は加熱器を通す。

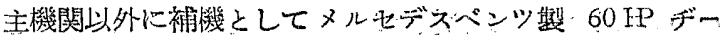
ゼル機関がある。これは $30 \mathrm{~kW}$ 発電用にして回轉数 $1,780 /$ mnである。

(山口)

\title{
11. 鉄道及び鉄道車輌
}

\section{[146］佛国北部鉄道䎦合金製客車}

[Maurice Leroy, Gewichtsersparnis in Transportwesen, 1936, No. 3〜4, 図 26] 佛国北部鉄道に於ては以前その鋼 政車の部分品の一部例へば屝等に軽合金を用ひ重量整減に資 してるたが Paris 近郊線における列車回数の增加に 俳ひ高 加速度列車を必要と寸るに至り·1933 年同鉄道 Hellemmes
てはその楜用は佲ど不可能であるため特に7\%の $\mathrm{Mg}$ を含有 する $\mathrm{Al}$ 合金を用ふることにした。その特性は燒鈍の狀態に 於て彈性限界 $18 \mathrm{~kg} / \mathrm{mm}^{2}$, 引張强さ $36 \mathrm{~kg} / \mathrm{mm}^{2}$; 延 18 22\%

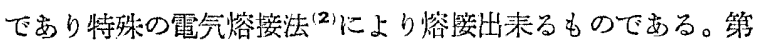

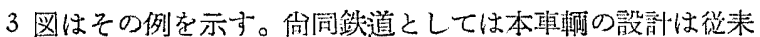
のものに比し相賞異色あり、且上記倠用材の使用成續に就て

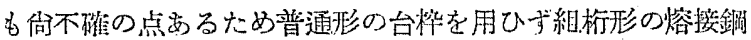

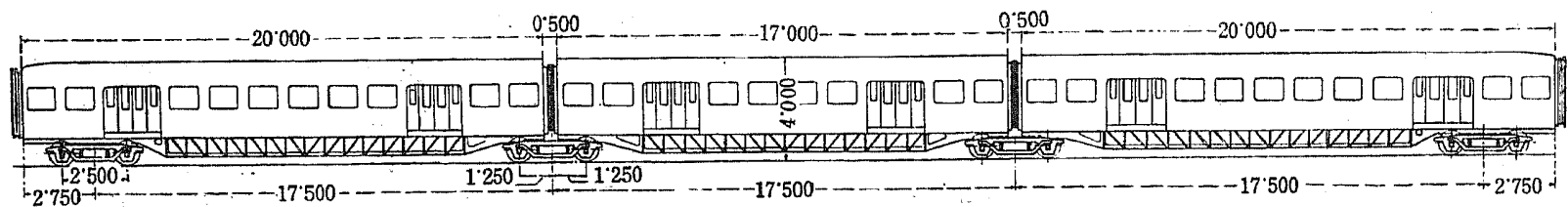

第 1 圆

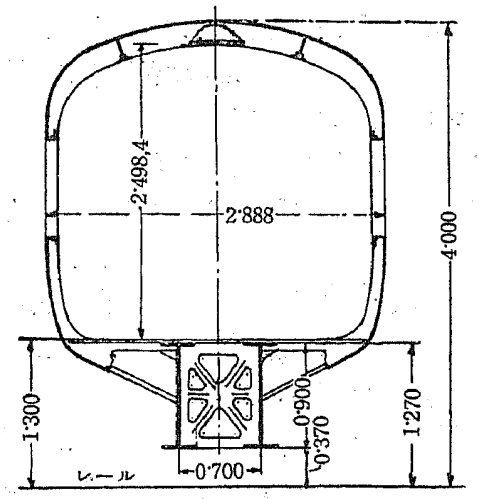

第 2 圖 断 面
工場に於て 3 輛連結 75 t の俥量関節客車 (第 1 図) を製作し た。 定員は 534 座席は 274 である。 本文はその重量軧減 に就き枱べてある。 A1 合金特にデュ ラルミンの熔接は施 行後熱處理を必要と するために本車輛の 如き樦造（第 2 図， を有するむのに対し

(1)
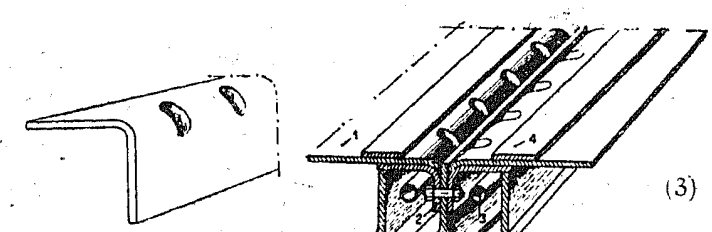

(2)

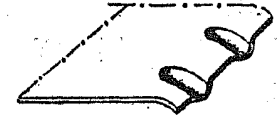

第 3

㘣

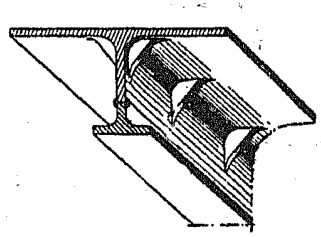

(4) 落昭

(1) 設针に関しては kevue Générale des chemins de fer. 1935-11

3) $\leftarrow$ (4) 完成せる\&口

(3) 趽接中の形

1: 板

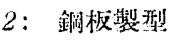

3: 加䇠營

$$
\text { ける柀 }
$$

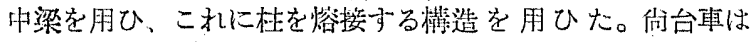
Pennsylvania 形であり特殊鍽を熔接し組立て特に䡫量に出 来てるる。枕梁には Spencer 式ゴム緩㣫器を有す。軸箱は
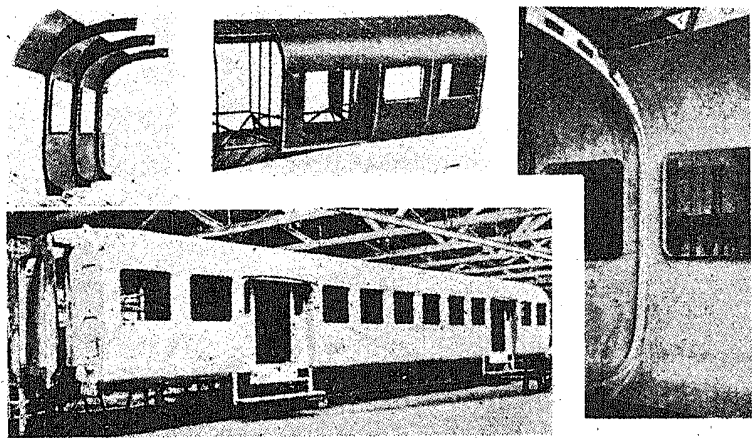

第 4 圖 揢揬構造

(1) 粽接用板端部を曲げ角 に阳を附す

(2) 揢接前の板端部

4：板 1 を型 2 に取付

Isothermos 式を用ひ制動简は A1 錝物である。第 1 裴は以 上各部詳縕の重量を示小。

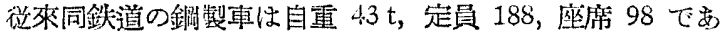

(2) Revue de l'Aluminium 1934-9 及び 10 䐨照

[第 39 告第 234 号 


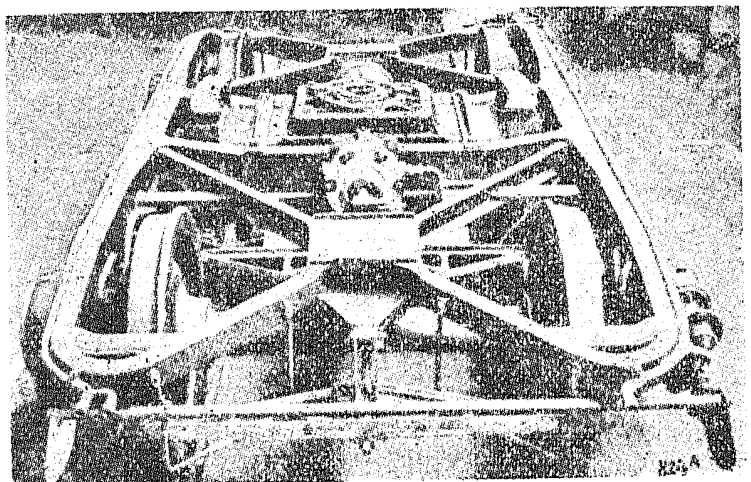

管 5 熙古車

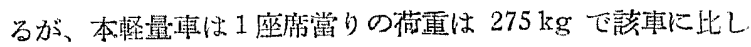
$37.5 \%$ 減少となる。その內蜀は骨組 16\%，台車 $12 \%$ ，棍及 び湩結裝置 6\% 及び內部部分品 3.5\% である。現在 90 哩/

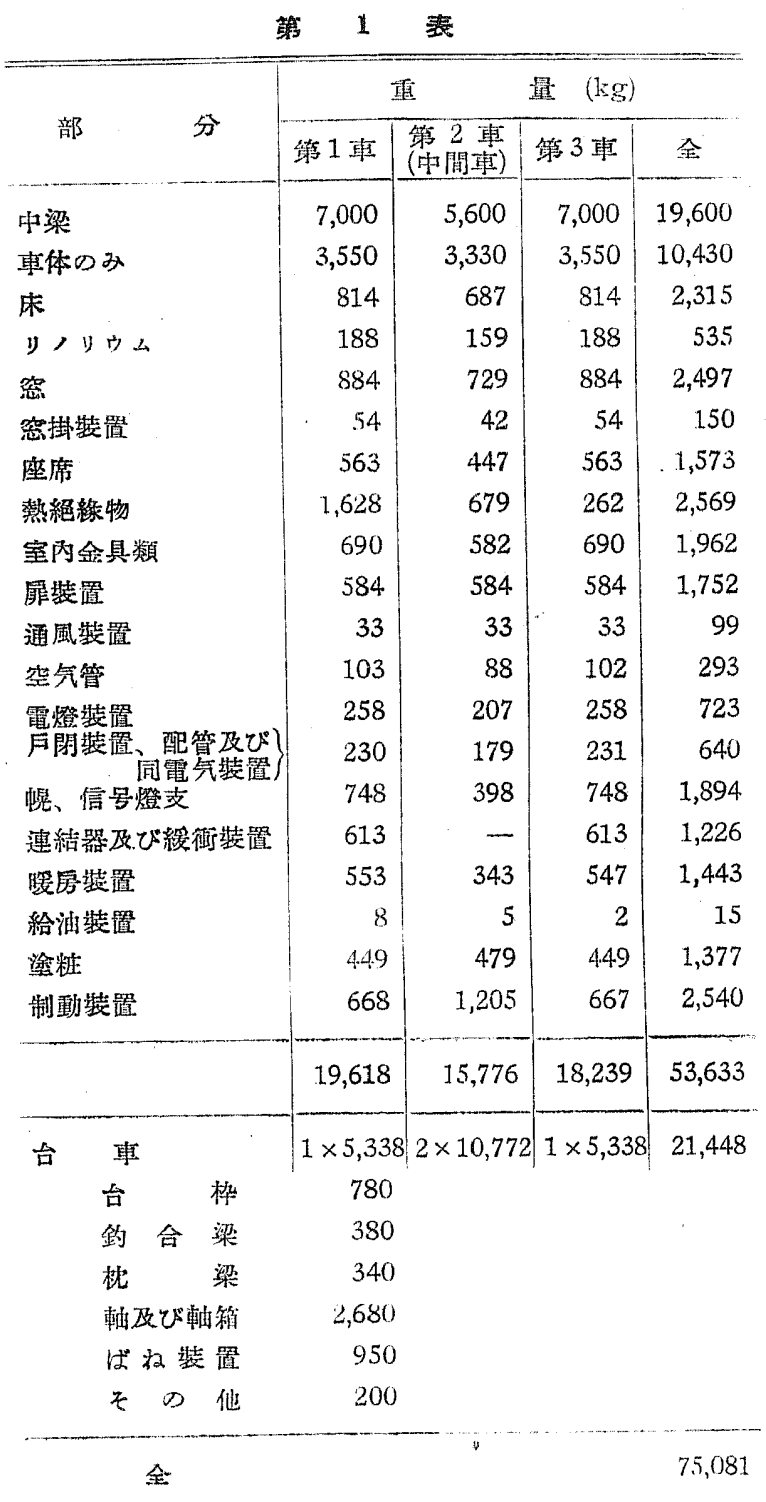

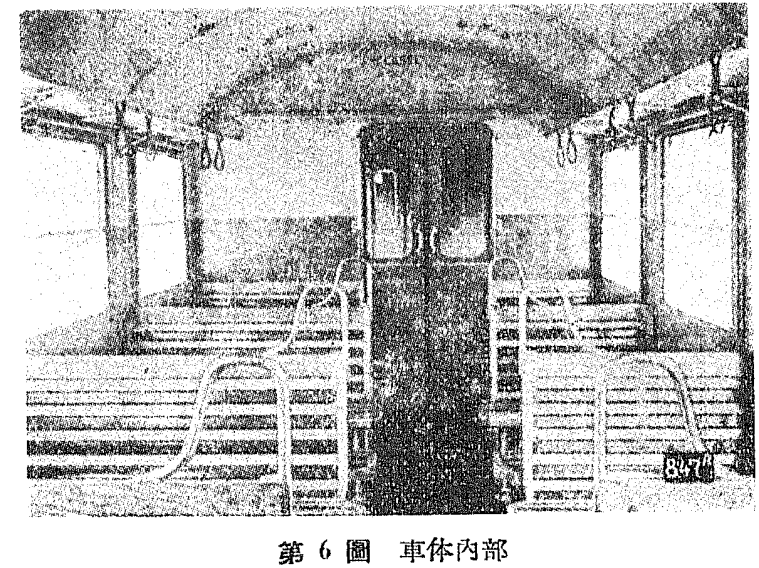

h の最大息度で連轉してるるが成績は長好である。

(片山践)

\section{[147］急行用㙨関車の主連棒受金}

[L. Schneider, Organ, 1935-11-15, Jg. 90, Ht. 22, 頁 448 451，図 17，表 1] 急行用機関車の主連㯃受金及びク ランクピンに作用する力の分布狀態立に適當な給油方法等に

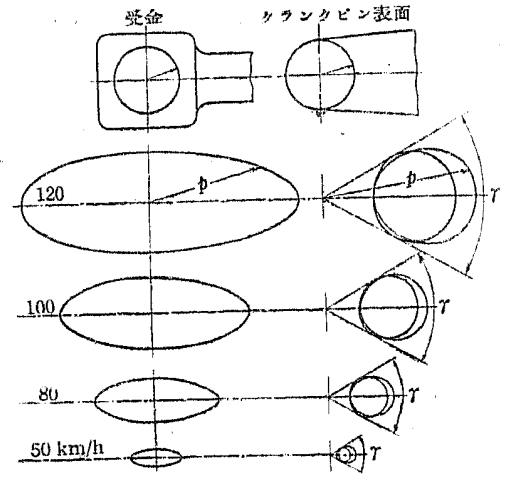

就て研究するた め伊太利で機関 荲 Gr 691 及ひ Gr 685 に依つ て試驗を行つた。 主連棒のクラ ンクビン及び受 金に作用する力 はビストン卧力、 往復部重量に基 く䍛性力及び回 轉部分の逜心力

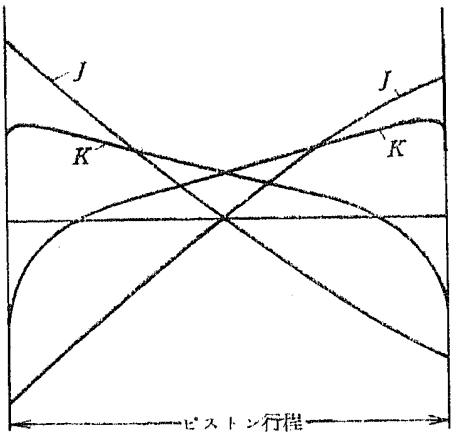

第 1 图 (上) 第 2 圖 (下) 等の合成されたるの て、、絕气運轉中には 後の 2 者のみが作用 する。第1図は絶气 運轉中外側主連棒受 金及びそのクランク ピン面に作用する力 を Gr 691 機関㖩 就て速度別に示した すのである。これに よるとクランクビン 表面の力を受ける部分の張る角度 $\gamma$ は常に一定の値を示し てるることがわかる。給气濐轉中はこれにピストン力が加る から各部の受ける力は最大憒性力 $J_{\max }$ と最大ビストン力 $K_{\max }$ の値如何によつて翂つて未る。

$J_{\text {max }}-K_{\max }>0$ (第 2 図) の場合には力の分布は第3図の菉 になる。弐 $J_{\max }-K_{\max }<0$ の暘合には更に

昭和 11 年 10 月] 